\title{
Article \\ Phytolith and Calcitic Spherulite Indicators from Modern Reference Animal Dung from Mediterranean Island Ecosystems: Menorca, Balearic Islands
}

\author{
Marta Portillo ${ }^{1,2,3, *}$, Kate Dudgeon ${ }^{2}$, Montserrat Anglada ${ }^{4}$, Damià Ramis ${ }^{4}$, Yolanda Llergo ${ }^{3}$ and Antoni Ferrer ${ }^{5}$ \\ 1 Department of Archaeology and Anthropology, Archaeology of Social Dynamics (2017SGR 995), \\ Institución Milà y Fontanals de Investigación en Humanidades (IMF), Spanish National Research \\ Council (CSIC), 08001 Barcelona, Spain \\ 2 Department of Archaeology, University of Reading, Reading RG6 6AB, UK; k.dudgeon@pgr.reading.ac.uk \\ 3 Department of Prehistory, Autonomous University of Barcelona, 08193 Cerdanyola del Vallès, Spain; \\ yolanda.llergo@gmail.com \\ 4 Museu de Menorca, 07701 Mahon, Menorca, Balearic Islands, Spain; \\ montserratanglada@museudemenorca.com (M.A.); damiaramis@gmail.com (D.R.) \\ 5 Institut Menorquí d’Estudis, 07701 Mahon, Menorca, Balearic Islands, Spain; antoniferrer1@gmail.com \\ * Correspondence: mportillo@imf.csic.es
}

check for updates

Citation: Portillo, M.; Dudgeon, K.; Anglada, M.; Ramis, D.; Llergo, Y.; Ferrer, A. Phytolith and Calcitic Spherulite Indicators from Modern Reference Animal Dung from Mediterranean Island Ecosystems: Menorca, Balearic Islands. Appl. Sci. 2021, 11, 7202. https://doi.org/ 10.3390/app11167202

Academic Editor: Jordi Revelles

Received: 28 May 2021

Accepted: 26 July 2021

Published: 4 August 2021

Publisher's Note: MDPI stays neutral with regard to jurisdictional claims in published maps and institutional affiliations.

Copyright: (c) 2021 by the authors. Licensee MDPI, Basel, Switzerland. This article is an open access article distributed under the terms and conditions of the Creative Commons Attribution (CC BY) license (https:// creativecommons.org/licenses/by/ $4.0 /)$.

\begin{abstract}
This study illustrates the contribution of plant and faecal microfossil records to interdisciplinary approaches on the identification, composition, taphonomy and seasonality of livestock dung materials. The focus is on the taphonomy of opal phytoliths and calcitic dung spherulites embedded within modern faecal pellets collected from pasture grounds and pens from a range of animals, including cattle, sheep and pigs from three different farms and seasons of the year in Menorca (Balearic Islands, Spain) declared a Biosphere Reserve by UNESCO. Modern reference materials provide comparative plant and dung microfossil indicators on factors affecting the formation, composition, preservation and decay of animal faeces, as well as on the diverse environmental and anthropogenic aspects influencing these. The reported results show relevant changes in phytolith and spherulite composition according to animal species and age, livestock management, seasonality, and grazing and foddering regimes. Both microfossil records provide fundamental information on taphonomic issues that are understudied, such as the variation in the digestibility among different species, including under investigated animals such as pigs, as well on the seasonality of plant and faecal microfossils that are excreted with dung as an important material for reconstructing human-environment interactions which is commonly overlooked in archaeology.
\end{abstract}

Keywords: Mediterranean; Balearic Islands; livestock dung; modern dung reference collection; phytoliths; dung spherulites

\section{Introduction}

Over the last few decades varied archaeobotanical and geoarchaeological methodological approaches have highlighted the fundamental importance of livestock dung as it embeds critical information on diverse ecological and past cultural ways of life ([1,2] and references therein). A range of studies conducted on modern dung materials including phytolith and dung spherulite records, have investigated herbivore faeces and stabling floors, primarily from herds of sheep, goats, and cattle, although studies on other important animals in many areas of the world such as suids as well as commensals are still underdeveloped [3-12]. Most of the basic processes of formation, composition, morphology and taphonomy of both opaline phytoliths [13-21] and calcitic dung spherulites [1,3,4,22-25] are well understood. However, critical information on taphonomic issues, such as the variation in their digestibility and durability among different animal producers, including less investigated species such as pigs, linked to dietary practices, age/sex-based aspects, as 
well on seasonality of these plant and faecal microfossils that are excreted with dung have not yet been fully investigated.

The current study builds on previous work on modern dung, primarily from ovicaprines and cattle, to address livestock management within the local landscape and to elucidate links between animal and plant resources through the study of the phytoliths and calcitic spherulite records embedded within animal dung deposits from Mediterranean inland ecosystems $[9,10,26-29]$. This study expands the modern reference records with new modern dung materials from Menorca (Balearic Islands, Spain). The island is home to a remarkable diversity of ecosystems and rural landscapes, as well as to rich archaeological late Bronze and Iron Age (Talayotic) heritage. The archaeofaunal records indicate that the main domestic species widespread across the Mediterranean, sheep (Ovis aries), goat (Capra hircus), cattle (Bos taurus), pig (Sus domesticus), as well as other domestic species such as $\operatorname{dog}$ (Canis familiaris) and rodents (house mice, rats), were introduced to the island along with the first human populations during the III millennium cal BC [30-34]. The faunal assemblages from later Talayotic Iron Age sites such as Cornia Nou in Mahon, located in our research area on the eastern side of Menorca (Figure 1), have revealed insights into ovicaprine herding (Ovis, Capra), and to a lesser extent from cattle (Bos taurus) and suids (Sus domesticus), as well as pollen assemblages indicative of herbaceous ruderal and nitrophilous vegetation related to husbandry $[35,36]$. Further direct evidence from dung remains come from the Talayotic settlement of Torre d'en Galmés (Alaior), in the southern portion of the island, where the identification through soil micromorphology of spherulithic ashes within domestic contexts from building areas points to the use of animal dung a source of fuel $[37,38]$.
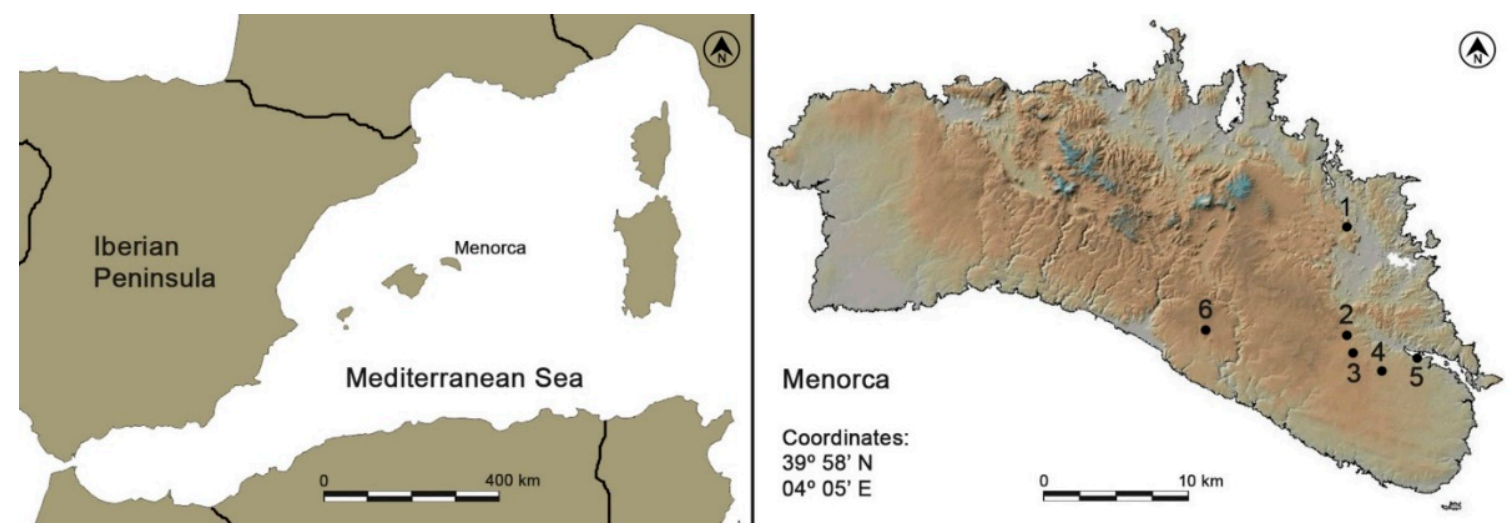

Figure 1. Localities in Menorca cited in the text. (1) Es Capell de Ferro (Mahon); (2) Algendaret Nou (Mahon); (3) Talatí de Dalt (Mahon), (4) Cornia Nou (Mahon); (5) Museum of Menorca (Mahon); (6) Torre d'en Galmés (Alaior).

In light of these previous studies, the focus in the current work is on the phytolith and calcitic dung components of modern faecal pellets collected from pasture grounds and pens from diverse adult and young animals, including cattle and sheep in addition to the lesser investigated pigs [9]. Dung samples correspond to three neighboring farms located in Mahon, displaying varied agricultural and livestock management strategies and animal diets. Furthermore, an innovative aspect of the reported research is the sampling strategies, focusing on the collection of a range of dung materials from different periods of the year to evaluate variations on seasonality of phytolith and calcitic spherulithic microfossils that are excreted with dung, as well as differences in their composition according to animal species and age, livestock management, and grazing and foddering regimes. The main objective is to contribute a better understanding of both microfossil records, in order to evaluate their implications for the identification of dung assemblages as fundamental reference frameworks for the interpretation of these important materials for reconstructing human-environment interactions which are commonly overlooked in archaeology. 


\section{Study Area}

The study area is located on the southeastern edge of Menorca (Balearic Islands) close to the port of Mahon, considered one of the largest natural harbors in the Western Mediterranean (Figure 1). The area has a typically temperate Mediterranean climate with mild winters and warm, dry summers, and considerable fluctuations in rainfall. This area receives $650 \mathrm{~mm}$ of annual rain on average, characterized by a high annual variability, with rainfall mostly concentrated during the seasons of spring and autumn [39]. The total rainfall registered in the Mahon Airport weather station (B893) during the sampling field seasons (from September 2018 to June 2019) was $225 \mathrm{~mm}$ (Table 1). The research area is placed on a chromic cambisol in the Miocene platform that occupies the southern half of the island of calcarenite allowing seasonal flowing to seep through to the water tables with its height close to the sea level. Cambisols are suitable for agriculture as they provide available nutrients and depth for optimal growth, and these are the home of most Talayotic settlement sites [40]. The current vegetation in the area displays Oleo-Ceratonion communities and is dominated by sclerophyllous plants, whereas in deeper soils the Cyclamini-Quercetum ilicis communities are widespread, and its degradation allows the occurrence of large areas with Aleppo pine (Pinus halepensis) and mastic (Pistacia lentiscus) [41].

Table 1. Total monthly precipitation and average relative humidity records from Mahon Airport weather station, Menorca. Data obtained from the State Meteorological Agency (AEMET).

\begin{tabular}{ccc}
\hline Month/Year & Precipitation $\mathbf{( m m )}$ & Humidity (\%) \\
\hline September 2018 & 57.4 & 73 \\
October 2018 & 43.1 & 77 \\
November 2018 & 25.8 & 82 \\
December 2018 & 11.3 & 83 \\
January 2019 & 46.3 & 75 \\
February 2019 & 3.8 & 77 \\
March 2019 & 4.6 & 74 \\
April 2019 & 28.4 & 73 \\
May 2019 & 4.1 & 61 \\
June 2019 & 0.2 & 60 \\
\hline Total precipitation/average humidity & 225 & 73.5 \\
\hline
\end{tabular}

At present, cattle and dairy farming in particular play a key role in the island, with a production characteristic of the Western Mediterranean region, traditionally dry land in winter and with a use based on grazing [42]. The Balearic Islands have a total of 213 dairy farms, with an annual quota of 84 million kilos of milk (2011 data in [42]). Most of these farms are located in Menorca, which represents around $73 \%$ of the total milk production of the islands, intended mainly for the production of cheese of the Mahon-Menorca protected designation of origin (Mahon-Menorca PDO). In addition to livestock farming of cattle, sheep and pig, the latter for meat and minorcan pork sausage (locally called sobrassada), many of these farms on the island produce fodder (mainly barley and oat) and use manure on their own farmland as fertilizer. The widespread traditional system of parceling and division of the land comprise a wide mesh of drywalls, namely pedra seca or dry-wall constructions. UNESCO declared the island a biosphere reserve in October 1993, which is characterized by a rich diversity of Mediterranean natural habitats and resources, but also by a remarkable tradition of rural landscapes [43-46].

\section{Materials and Methods}

\subsection{Modern Dung Material Sampling}

The modern materials examined in the current study (cow, sheep and pig dung pellets) belong to three neighboring farms, Algendaret Nou, Talatí de Dalt, and Es Capell de Ferro, located in the eastern portion of Menorca close to the port of Mahon and many Talayotic archaeological sites (Figure 1). Previous experimental work in one of these 
settings of Mahon, Algendaret Nou, reported on the plant microfossil records from barley crop production (phytoliths and pollen grains) manured with their own farmland cattle dung, to assess the impact on cereal processing through grain cleaning and grinding into flour using Talayotic stone tools [47]. The present work enlarges modern reference studies and focuses in particular on livestock management and grazing/foddering records, with the sampling of new faecal materials from penning areas and pasture grounds, including informal interviews and photography within three farms using a questionnaire following ethical protocols, and with full permission. The aim in collecting modern dung remains was to study different grazing and foddering regimes, according to three different animal species and age, livestock management, and grazing and foddering regimes, including less investigated animals such as pigs, as well on seasonality of plant and faecal microfossils that are excreted with dung. This study focused on fresh dung samples primarily from ruminants (cattle and sheep), as these are prolific producers of dung spherulites [4], in addition to herbivorous pigs.

The dung samples collected in the current study reported below come from animals kept either in enclosures or semi-free-ranging herds within parceled pastoral grounds during most of the year. Cattle and pigs display a grass-rich diet based on grazing and supplementary fodder, primarily barley or oat chaff from the household's own production (in the case of pigs either barley grains or barley flour), in contrast with sheep which are grazers with no supplementary fodder. Diet regimes are diverse according to the different farm choices and resource availability across the different periods of the year (Figure 2). Sample collection took place in three different seasons: early autumn (end of September 2018), winter (middle of February 2019), and late spring-early summer (middle of June 2019). Table 2 summarizes the main livestock and crop management and production characteristics along with the number of animals kept, the secondary use of dung as fertilizer from the farm's own livestock for crops (cattle dung) or gardens where fruit and vegetables are cultivated for food and fodder (either cattle or pig dung), penning and grazing/foddering within their own farm crop fields and pastoral parceled grounds. Livestock grazing and foddering regimes are then summarized according to the three main seasonal periods reported in the present study-early autumn, winter, and late spring-early summer (Table 3). All samples were stored at the Museum of Menorca in Mahon prior to exportation to the Autonomous University of Barcelona for microfossil analyses. A total number of twenty-eight dung samples were selected for integrated phytolith and calcitic dung spherulite studies and served as modern reference standards in this study. 

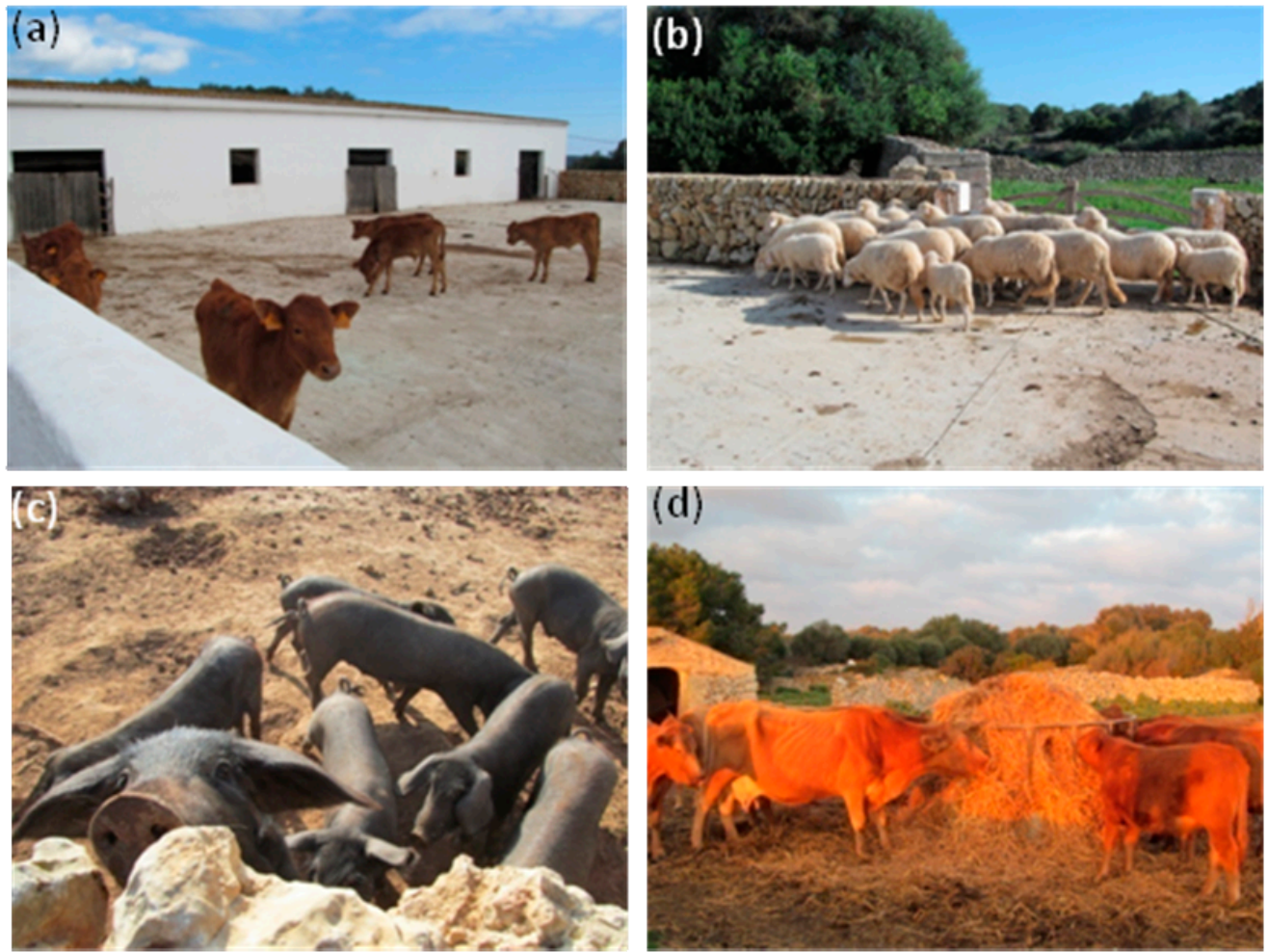

(e)
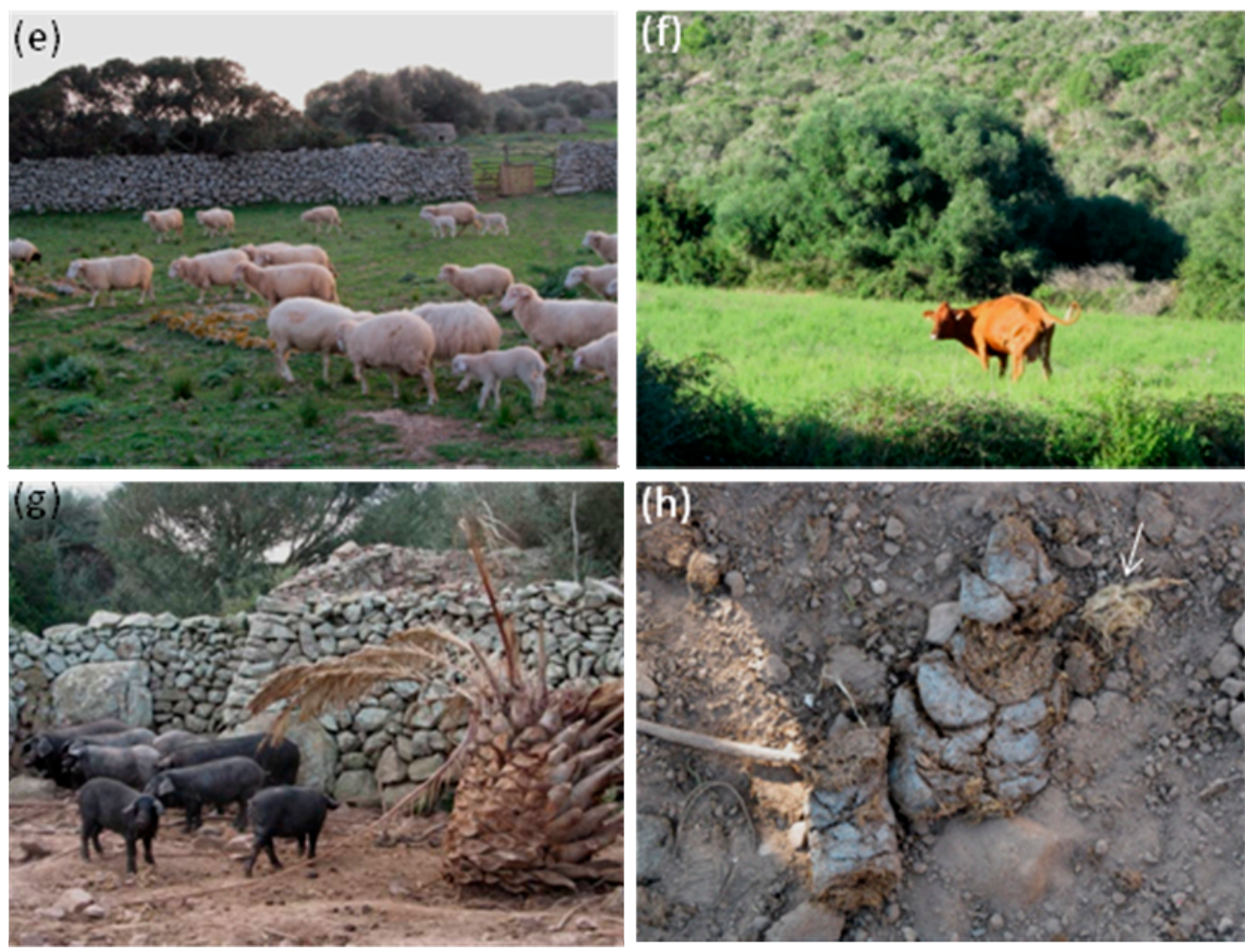

Figure 2. Livestock management and seasonal grazing and foddering at the study area, Mahon (Menorca). AN: Algendaret Nou; TD: Talatí de Dalt; CF: Es Capell de Ferro. (a) cattle penning, AN, February 2019; (b) sheep grazers, AN, September 2018; (c) pigs kept in enclosures, AN, September 2018; (d) cattle eating oat straw fodder, TD, February 2019; (e) sheep grazers within the pasture ground, TD, February 2019; (f) daily cattle grazing within the pasture grounds, CF, September 2018; (g) pigs kept in an open-air enclosure, CF, February 2019; (h) pig dung and chewed palm leaves (arrow) within the same enclosure CF, September 2018. 
Table 2. Livestock and crop management practices. C: cattle, S: sheep, P: pig, Ch: chicken, R: rabbit.

\begin{tabular}{|c|c|c|c|}
\hline Animal and Crop Management & Algendaret Nou (26 Ha) & Talatí de Dalt (64 Ha) & Capell de Ferro (95 Ha) \\
\hline Number of animals & $\begin{array}{l}\text { C: } 9 \text { adults (1 male) and } 7 \text { calves } \\
\text { S: } 15 \\
\text { P: } 11 \\
\text { Ch: } 70\end{array}$ & $\begin{array}{l}\text { C: } 11 \text { adults (1 male) and } 10 \text { calves } \\
\text { S: } 70\end{array}$ & $\begin{array}{c}\text { C: } 19 \text { adults (1 male) and } 12 \text { calves } \\
\text { P: } 21 \\
\text { Ch: } 87 \\
\text { R: } 1\end{array}$ \\
\hline Livestock production & Meat, cheese, eggs & Meat & $\begin{array}{l}\text { Meat, Minorcan pork sausage } \\
\text { (sobrassada) }\end{array}$ \\
\hline Crops (rotation) & $\begin{array}{l}\text { Barley }(2 \mathrm{Ha}) \text { and oat }(2 \mathrm{Ha}) \text { for } \\
\text { livestock fodder }\end{array}$ & Oat for livestock fodder (18 Ha) & $\begin{array}{c}\text { Oat }(8 \mathrm{Ha}) \text { and barley for fodder } \\
\text { (6 Ha), sulla (Hedysarum) for } \\
\text { silage ( } 5 \mathrm{Ha})\end{array}$ \\
\hline Fertilizer & $\begin{array}{l}\text { Dung from own livestock, } \\
\text { seaweed (macroalgae, salt), } \\
\text { purchased fertilizer }\end{array}$ & $\begin{array}{l}\text { Dung from own livestock during } \\
\text { grazing, purchased fertilizer }\end{array}$ & $\begin{array}{l}\text { Dung from own } C \text { during grazing, } \\
\text { purchased fertilizer; } P \text { dung from } \\
\text { penning cleaning used to fertilize } \\
\text { the vegetable garden }\end{array}$ \\
\hline Penning & $\begin{array}{c}\mathrm{C} / \mathrm{S} \text { separately adults and calves, } \\
\text { but } \mathrm{S} / \mathrm{P} \text { non penned }\end{array}$ & No & $\begin{array}{c}\text { P/R separately adults and calves } \\
\text { (3 palms within the enclosure), } \\
\text { but } C \text { non penned }\end{array}$ \\
\hline Grazing/ foddering & $\begin{array}{l}\text { Grazing within the farm fields; C: } \\
\text { straw, own barley/oat grains, } \\
\text { purchased feed; P: barley grains, } \\
\text { whey from own cheese } \\
\text { manufacture }\end{array}$ & $\begin{array}{l}\text { Grazing within the farm fields; C: } \\
\text { straw, own oat straw and grain } \\
\text { cultivated and processed at the } \\
\text { farm }\end{array}$ & $\begin{array}{l}\text { C grazing within the farm fields; } \\
\text { C: straw, own oat grain, sulla } \\
\text { (Hedysarum) silage made from } \\
\text { own crops; P: own barley flour } \\
\text { produced at the farm; purchased } \\
\text { feed for Ch/R }\end{array}$ \\
\hline
\end{tabular}

Table 3. Seasonal grazing and foddering with indication of supplementary feed (SF). C: cattle, S: sheep, P: pig.

\begin{tabular}{|c|c|c|c|c|}
\hline Season & Animal & Algendaret Nou & Talatí de Dalt & Capell de Ferro \\
\hline \multirow{3}{*}{ Early Autumn } & $\mathrm{C}$ & $\begin{array}{l}\text { Grazing within the farm pasture fields } \\
\text { (calves close to the house), fallow crop } \\
\text { fields (rotation), own straw barley, } \\
\text { purchased feed (barley, wheat, oat for } \\
\text { adults and barley flour for calves) (SF) }\end{array}$ & $\begin{array}{l}\text { Grazing within the farm } \\
\text { pasture fields close to the } \\
\text { house, fallow crop fields } \\
\text { (rotation), straw, own oat } \\
\text { grains in late summer (SF) }\end{array}$ & $\begin{array}{l}\text { Grazing within the farm } \\
\text { pasture fields (changing } \\
\text { locations), fallow crop fields } \\
\text { (rotation), straw own oat } \\
\text { and sulla (Hedysarum) } \\
\text { silage (SF) }\end{array}$ \\
\hline & $\mathrm{S}$ & $\begin{array}{l}\text { Grazing within the farm pastures and } \\
\text { fallow crop fields }\end{array}$ & $\begin{array}{l}\text { Grazing within the farm } \\
\text { pastures and fallow } \\
\text { crop fields }\end{array}$ & $\mathrm{n} / \mathrm{a}$ \\
\hline & $\mathrm{P}$ & $\begin{array}{c}\text { Grazing within the farm pasture fields } \\
\text { (changing locations), own barley } \\
\text { grains, barley flour only in late } \\
\text { autumn (SF) }\end{array}$ & ${ }^{2}$ & $\begin{array}{l}\text { Own barley flour processed } \\
\text { at the farm }\end{array}$ \\
\hline \multirow{3}{*}{ Winter } & $\mathrm{C}$ & $\begin{array}{l}\text { Grazing within the farm pasture fields } \\
\text { (calves close to the house), own straw, } \\
\text { purchased feed (barley, wheat, oat and } \\
\text { barley) (SF) }\end{array}$ & $\begin{array}{l}\text { Grazing fields close the } \\
\text { house, own oat straw (SF) }\end{array}$ & $\begin{array}{c}\text { Grazing within the farm } \\
\text { pasture fields (changing } \\
\text { locations, rotation), own oat } \\
\text { straw, own sulla (Hedysarum) } \\
\text { silage (SF) }\end{array}$ \\
\hline & $\mathrm{S}$ & Grazing within the farm pastures & $\begin{array}{l}\text { Grazing within the farm } \\
\text { pastures }\end{array}$ & $\mathrm{n} / \mathrm{a}$ \\
\hline & $\mathrm{P}$ & $\begin{array}{l}\text { Grazing within the farm pasture fields } \\
\text { (changing locations), whey from own } \\
\text { cheese production, purchased barley } \\
\text { and flour (SF) }\end{array}$ & $\mathrm{n} / \mathrm{a}$ & $\begin{array}{l}\text { Own barley flour processed } \\
\text { at the farm }\end{array}$ \\
\hline \multirow{3}{*}{$\begin{array}{l}\text { Late Spring/Early } \\
\text { Summer }\end{array}$} & C & $\begin{array}{l}\text { Grazing within the farm pasture fields } \\
\text { (calves close to the house), straw, } \\
\text { purchased feed (barley, wheat, oat), } \\
\text { green leaves (SF) }\end{array}$ & $\begin{array}{l}\text { Grazing within the farm } \\
\text { pasture fields close to the } \\
\text { house, straw, own oat (SF) }\end{array}$ & $\begin{array}{l}\text { Grazing within the farm } \\
\text { pasture fields (changing } \\
\text { locations, rotation), straw, } \\
\text { own oat (SF) }\end{array}$ \\
\hline & $\mathrm{S}$ & Grazing within the farm pastures & $\begin{array}{l}\text { Grazing within the } \\
\text { farm pastures }\end{array}$ & $\mathrm{n} / \mathrm{a}$ \\
\hline & $\mathrm{P}$ & $\begin{array}{l}\text { Grazing within the farm pasture fields } \\
\text { (changing locations), purchased barley, } \\
\text { own barley in late spring, no flour (SF) }\end{array}$ & $\mathrm{n} / \mathrm{a}$ & $\begin{array}{l}\text { Own barley flour processed } \\
\text { at the farm }\end{array}$ \\
\hline
\end{tabular}

\subsection{Phytolith and Dung Spherulite Analyses}

Dung materials including cow, sheep and pig dung pellets were dried and ashed in laboratory-controlled conditions (at $500{ }^{\circ} \mathrm{C}$ for $4 \mathrm{~h}$ using a muffle furnace). Phytolith analy- 
ses followed the methods of Katz and colleagues [48]. A weighed aliquot of $40 \mathrm{mg}$ of ashed material was treated with $50 \mu \mathrm{L}$ of a volume solution of $6 \mathrm{~N} \mathrm{HCl}$. Phytoliths were then concentrated with $450 \mu \mathrm{L} 2.4 \mathrm{~g} / \mathrm{mL}$ of sodium polytungstate solution $\left[\mathrm{Na}_{6}\left(\mathrm{H}_{2} \mathrm{~W}_{12} \mathrm{O}_{40}\right)\right]$. Aliquots of $50 \mu \mathrm{L}$ of material were mounted on microscope slides using $24 \times 24$ cover slips. Phytoliths were examined in random fields at $\times 200$ and $\times 400$ magnification using an BX-43 optical microscope. Photomicrographs were captured with a Color View (Olympus) camera. A minimum of 200 phytoliths with diagnostic morphologies were counted from each sample whenever possible. Morphological identification was based on modern plant reference collections from the Mediterranean area [10,17,49-51] and standard literature $[15,16,52-56]$. Where appropriate, the terms used to describe phytolith morphologies follow the International Code for Phytolith Nomenclature-ICPN 2.0 [57].

For dung spherulite analyses, samples of $40 \mathrm{mg}$ of ashed material were treated with $450 \mu \mathrm{L} 2.4 \mathrm{~g} / \mathrm{mL}$ of sodium polytungstate solution. Similarly to the phytoliths, microscope slides were also mounted with aliquots of $50 \mu \mathrm{L}$ of sample. A minimum of 200 spherulites were counted from each sample whenever possible at $\times 200$ magnification, with occasional examination at $\times 400$, under the optical microscope with cross-polarized light (XPL).

Samples were then compared to phytolith and spherulite ethnoarchaeological and experimental burning records of modern livestock dung materials that have followed a similar quantitative approach $[9,10,25-27,29,58]$. Principal component analysis (PCA) was conducted in IBM SPSS Statistics for Windows, version 25.0 (IBM Corp, Armonk, NY, USA) to investigate the relationships between the ratios of grass inflorescences to leaves/stems with the species (cow, sheep, pig), farm (and therefore foddering practice) and season. Scatterplots were generated to visually identify and highlight groupings.

\section{Results and Discussion}

\subsection{Phytolith Composition, Taphonomy and Seasonality}

A major aim in the current study was to assess variations in phytolith distributions and morphotype composition and whether these may be related to different animal defecators and livestock management, grazing and foddering practices, as well to seasonality of these particular plant microfossil assemblages that are embedded within the dung. The estimated phytolith numbers are based on abundances per weight of ashed dung material (Table 4). The relative abundances of the main consistent morphotypes identified in the whole assemblages are expressed as averages of percentages of the total identifiable phytoliths (Figures 3-5). Those phytoliths which were unidentifiable because of pitting and etching were recorded as weathered morphotypes. Ratios between individual (singlecelled phytoliths) and multicellular phytoliths (multi-celled or in anatomical connection) were also calculated. Both the weathered and multicellular records are widely used as indicators of the state of preservation of phytolith assemblages, as well as regarding the extent of silicification of plant cells e.g., $[10,17,27,50]$. In modern fresh dung standards it is recognized that phytolith morphological integrity and preservation may also be affected by either the extent of silicification of plant cells ingested, as well as their solubility during digestion and excretion and variation in gut and bowel conditions [25], closely related to ecology and variability in dietary practices, seasonality, animal producers and age-based aspects, among others. 


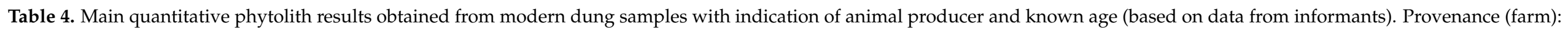
AN: Algendaret Nou; TD: Talatí de Dalt; CF: Es Capell de Ferro. Month: S: September 2018; F: February 2019 ; J: June 2019.

\begin{tabular}{|c|c|c|c|c|c|c|c|c|}
\hline Sample n. & Location-Month & $\begin{array}{l}\text { Phytoliths } 1 \mathrm{~g} \text { of Ashed } \\
\text { Material (Million) }\end{array}$ & $\begin{array}{c}\text { Phytoliths } \\
\text { Weathering (\%) }\end{array}$ & $\begin{array}{c}\text { Multicelled } \\
\text { Phytoliths (\%) }\end{array}$ & $\begin{array}{c}\text { Ratio } \\
\text { Individual/Multicelled } \\
\text { Phytoliths }\end{array}$ & $\begin{array}{c}\text { Grass Phytoliths } \\
\text { (\%) }\end{array}$ & $\begin{array}{c}\text { Ratio Grass } \\
\text { InfloresCences/Leaves- } \\
\text { Stems }\end{array}$ & Description \\
\hline 1 & AN-S & 0.7 & 5.3 & 9.6 & 9.4 & 88.1 & 0.53 & $\begin{array}{c}\text { Cow } \\
\text { (15 days) }\end{array}$ \\
\hline 6 & AN-S & 12.6 & 1.6 & 55 & 3.6 & 96.3 & 1.48 & Cow \\
\hline 7 & AN-S & 10.9 & 2.1 & 13.2 & 6.5 & 93.8 & 0.33 & Sheep \\
\hline 8 & AN-S & 7.1 & 3.6 & 4.5 & 21.2 & 97.4 & 8.76 & Pig \\
\hline 11 & TD-S & 10.2 & 0.8 & 6.3 & 14.9 & 94.6 & 0.48 & Cow \\
\hline 12 & TD-S & 9.9 & 3.6 & 11.7 & 7.6 & 92.4 & 0.37 & Cow \\
\hline 18 & CF-S & 7.5 & 4.8 & 13.5 & 6.4 & 91.3 & 5.25 & Pig \\
\hline 22 & CF-S & 8.4 & 1.9 & 5.8 & 16.1 & 95.4 & 8.2 & Pig \\
\hline 23 & CF-S & 6.6 & 0.9 & 4.7 & 20.4 & 98 & 8.6 & $\begin{array}{c}\text { Pig } \\
\text { (15 days) }\end{array}$ \\
\hline 26 & CF-S & 11.9 & 0.4 & 12.1 & 7.2 & 95.5 & 0.63 & Cow \\
\hline 28 & TD-F & 16.4 & 2.1 & 10.3 & 8.7 & 84.5 & 0.04 & $\begin{array}{l}\text { Sheep } \\
\text { (1 month) }\end{array}$ \\
\hline 29 & TD-F & 7.3 & 3 & 12.3 & 7.1 & 86.3 & 0.04 & Sheep \\
\hline 30 & TD-F & 18.6 & 0.8 & 8.7 & 10.5 & 95.9 & 0.28 & Cow \\
\hline 34 & AN-F & 0.8 & 5.5 & 3.9 & 24.4 & 87.1 & 0.35 & Pig \\
\hline 38 & AN-F & 16.2 & 2 & 19.5 & 4.1 & 95 & 0.39 & $\begin{array}{c}\text { Cow } \\
(3-4 \text { months })\end{array}$ \\
\hline 39 & AN-F & 23.2 & 1.2 & 8.5 & 10.7 & 95.9 & 0.66 & Cow \\
\hline 47 & AN-I & 4.1 & 1.8 & 6.8 & 13.8 & 95.9 & 7.63 & Pig \\
\hline 49 & AN-J & 12.8 & 3.2 & 8.2 & 11.2 & 91.1 & 0.61 & Sheep \\
\hline 50 & AN-J & 10.4 & 3.6 & 7.5 & 12.3 & 91.8 & 1.51 & $\begin{array}{l}\text { Sheep } \\
\text { (1 month) }\end{array}$ \\
\hline 54 & AN-J & 9.3 & 3.2 & 15 & 5.7 & 92.1 & 0.43 & $\begin{array}{c}\text { Cow } \\
(1 \text { month })\end{array}$ \\
\hline 56 & AN-J & 11.2 & 3 & 15.8 & 5.3 & 94.5 & 0.78 & Cow \\
\hline 57 & TD-J & 10.4 & 2.3 & 6.6 & 14.2 & 92.1 & 0.22 & Cow \\
\hline 60 & TD-J & 9.3 & 2.9 & 24.4 & 3.1 & 90 & 1.26 & Sheep \\
\hline 62 & CF-J & 17.9 & 0.8 & 8.9 & 10.3 & 93.3 & 0.16 & Cow \\
\hline 65 & CF-J & 3.4 & 1.3 & 12.4 & 7 & 93.3 & 6.25 & $\begin{array}{c}\text { Pig } \\
\text { (2-3 months) }\end{array}$ \\
\hline 66 & CF-J & 6.6 & 0.5 & 16.6 & 5 & 98.2 & 6.65 & Pig \\
\hline
\end{tabular}




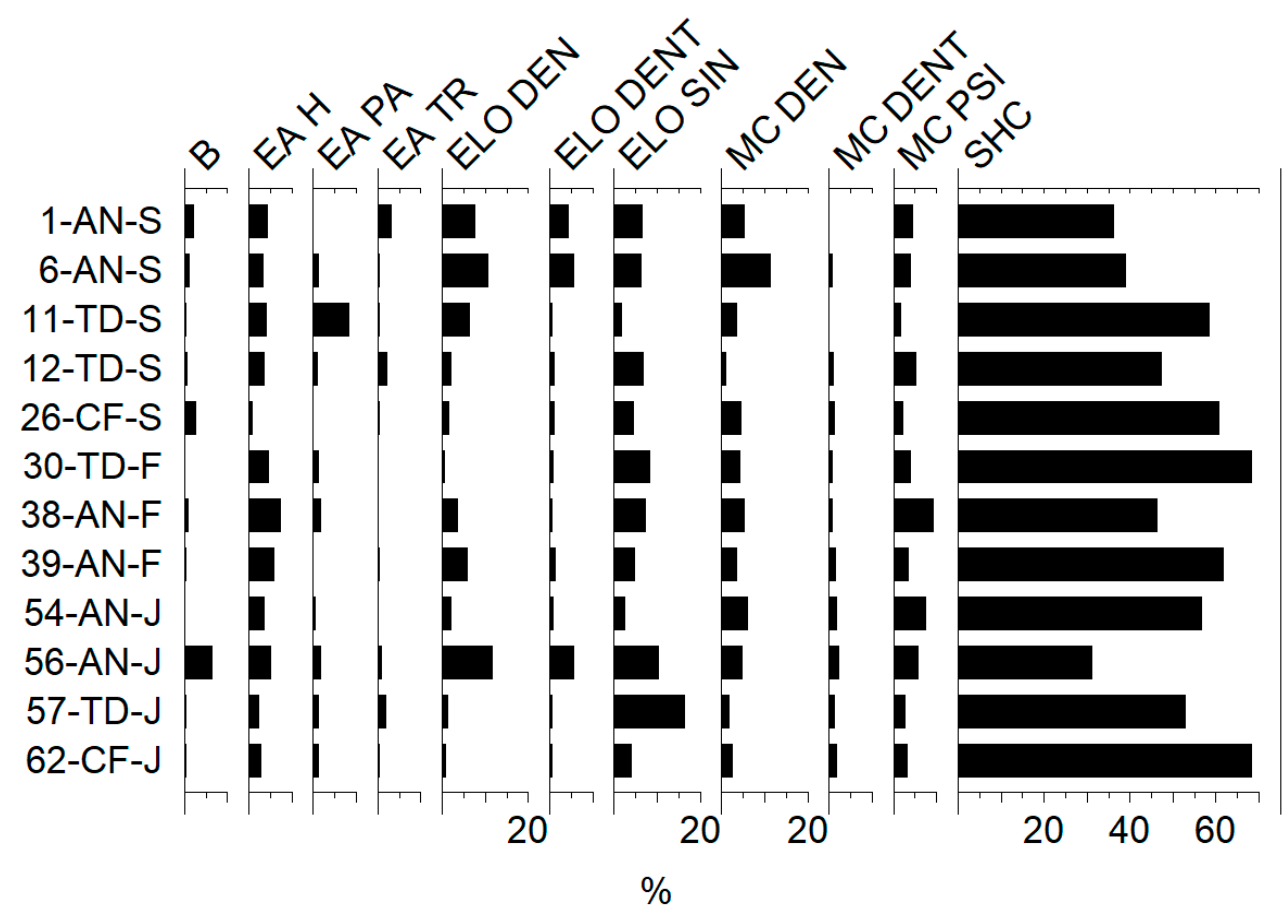

Figure 3. Relative abundances of main phytolith morphotypes obtained from cow dung samples with indication of sample number-farm-month. B = bulliform flabellate/blocky, EA H = Epidermal appendage hair, EA PA = Epidermal appendage papillate (papillae), EA TR = Epidermal appendage trichome (acute bulbosus), ELO DEN = Elongate dendritic, ELO DENT = Elongate dentate, ELO SIN = Elongate sinuate entire (psilate), MC DEN = Multicelled phytoliths of elongate dendritics (silica skeleton with dendritic/papillate/short cells/stomata), MC DENT = Multicellular structure of elongate dentates (silica skeleton with dentates/with papillate/short cells), MC PSI = Multicellular structure of elongate psilate (smooth), SHC= Short cell (rondel/trapeziform/bilobate).

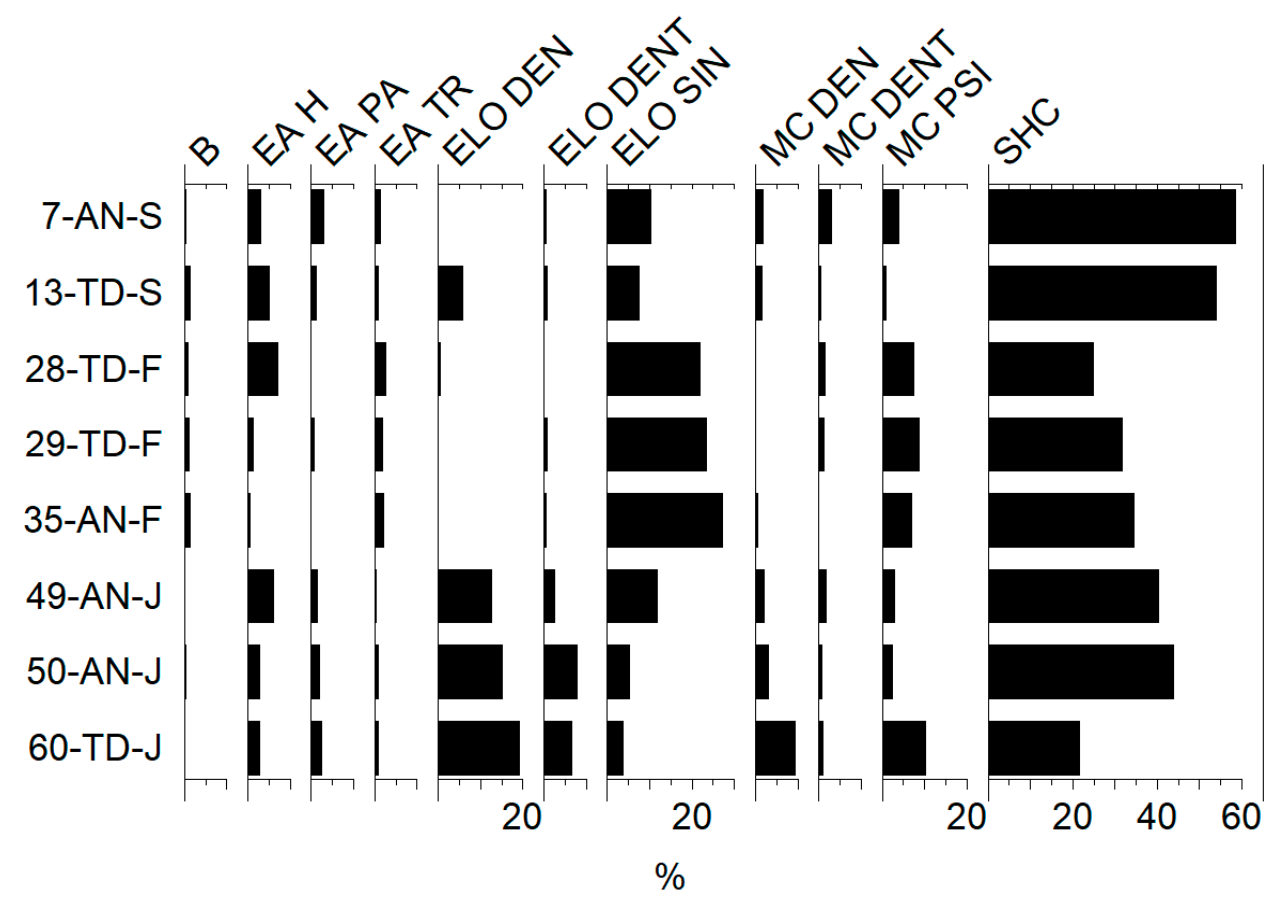

Figure 4. Relative abundances of main phytolith morphotypes obtained from sheep dung samples with indication of sample number-farm-month. 


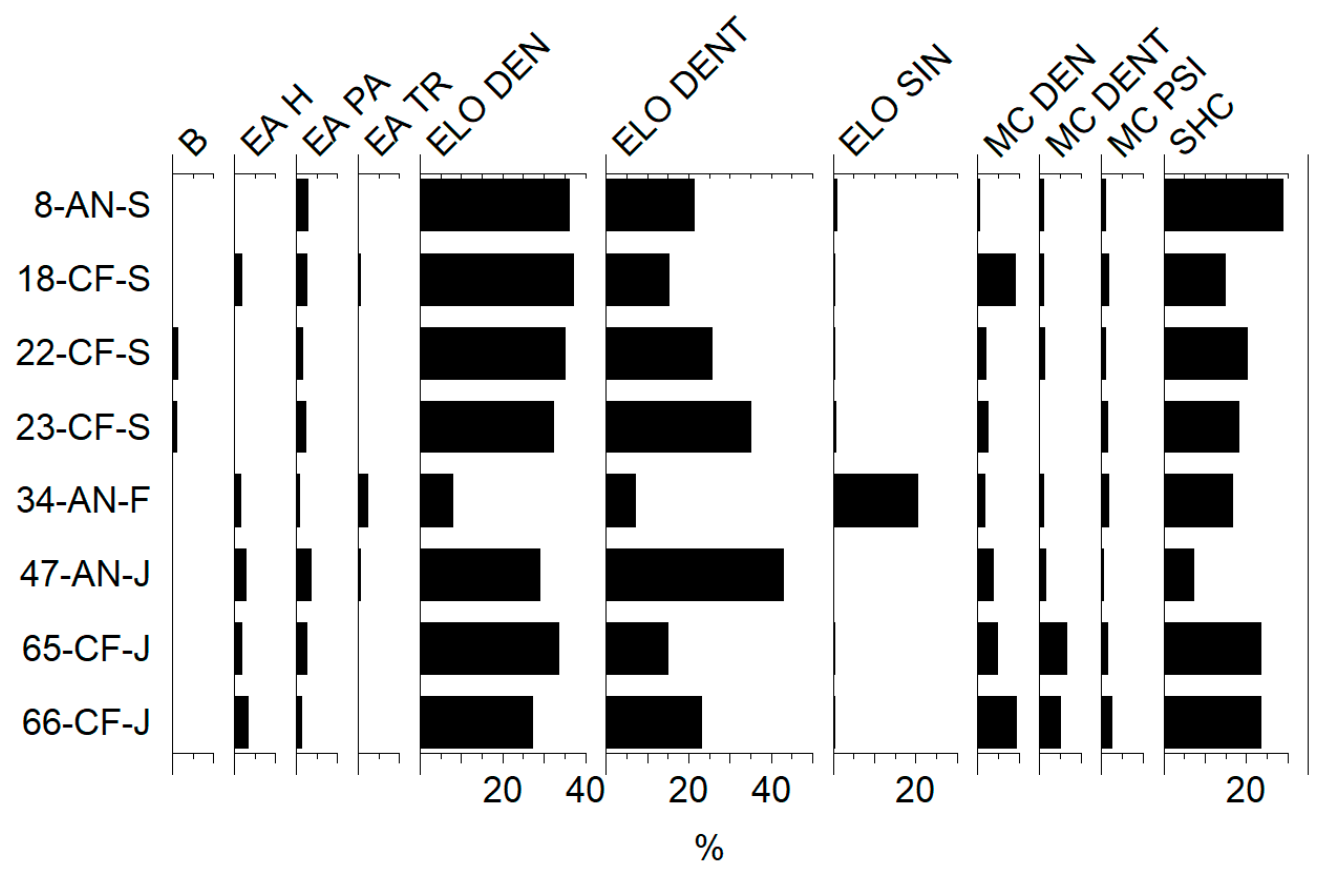

Figure 5. Relative abundances of main phytolith morphotypes obtained from pig dung samples with indication of sample number-farm-month.

Phytolith amounts range between 0.7 and 23.2 million per $1 \mathrm{~g}$ of ashed dung (Table 4). The low proportions of weathered phytoliths (below 6\%), together with the presence of multicellular phytoliths (anatomically connected) in most of the samples (up to $55 \%$, cow sample 6-AN-S), points towards generally good preservation conditions of the phytolith records. In general, cow dung samples contained more phytoliths than sheep and pig pellets in most of the assemblages. This is consistent with previously reported quantitative phytolith records from modern dung remains from ruminant herds from Mediterranean areas $[9,10,26,27,29]$. In the current study, this is particularly true for dung remains derived from adult or mature cattle, whereas for young animals around one month-old, phytoliths were noted in relatively lower amounts. This is clearly the case for the dung sample from a young cow collected from the property indoor enclosure of the household of Angendaret Nou (Figure 2a) whose diet was mostly based on lactation, ca. two weeks old (sample 1-AN$\mathrm{S}, 0.7 \mathrm{~m} \times 1 \mathrm{~g} /$ ashed dung, Table 4). Furthermore, the variable phytolith concentrations recorded among the sheep dung pellets, which are the only free-ranging animals that do not require any supplementary fodder and are more prone to browsing on the leaves and bark of shrubs and trees (Figure 2b), may be related to the differential production of phytoliths within dicotyledonous plants in comparison to prolific phytolith production of monocotyledonous plants, despite the similarities recorded on phytolith morphotype assemblages reported below (Figures 3-5). Also of significance are the greater proportions of multicellular or anatomically connected phytoliths within the cattle dung (up to $55 \%$, Table 4), with a diet based on crops from the property for fodder, barley in Algendaret Nou and oat in Talatí de Dalt and therefore represent a consistent and repetitive dietary pattern based on supplementary fodder (Tables 2 and 3). Conversely, the fresh dung pellets from suids represent generally lower phytolith multicellular proportions (between 4-16\%, Table 4). These variations could be explained in part due to possible differential digestive process of suids, but particularly to the known fodder which is based on complete barley grains in Algendaret Nou and barley flour in Es Capell de Ferro (Tables 2 and 3). Further research is needed to evaluate aspects of digestibility and preservation of phytoliths and other remains excreted with dung (e.g., pollen, non-pollen palynomorphs-NPPs), to better establish possible differences between ruminants and suids.

Although variations in the species of animal producers, dietary habits and grazing/foddering patterns through the seasons of the year may explain variations on the main 
phytolith morphotype records, grass short cells are by far the most dominant, although to a different extent. Short cells represent between $30-70 \%$ or more of the total grass phytoliths in the cow samples and around $20-60 \%$ in the sheep dung pellets, whereas short cells represent up to only $30 \%$ within the pig assemblages in this study (Figures 3-5). The short cell morphologies comprise mostly rondels (Figure 6a), although bilobates and polylobates from the Pooideae grass subfamily are also common in variable amounts, along with short cell towers (elongate) which are commonly produced in the Hordeum genus [10] and are also present in the pig assemblages representing human manipulation of fodder (barley complete grains and/or grinded into flour). Grass inflorescences were represented mainly by decorated elongate dentate (echinate) and dendritics in addition to epidermal cells such as papillate and hairs (Figure $6 \mathrm{~b}, \mathrm{c}$ ). Epidermal appendages produced by grass leaves and culms, including stomata, acute bulbosus (trichomes), and bulliforms, were also common in all the samples in variable amounts (Figures 3-5). Furthermore, these diagnostic morphotypes derived from the floral parts of grasses were abundantly noted among the cow and pig samples through the different periods of the year, whereas these are almost absent among the sheep dung samples collected in winter (coded as AN-F and TD-F samples, Figure 4). In addition to grass phytoliths, mostly short cells, polylobates, and elongate sinuate or psilate (smooth), characteristic morphotypes produced by dicotyledonous plants were also common among the winter sheep dung pellets, including epidermal appendages such as hairs and their bases, as well as irregular multicellular jigsaw phytoliths (Figure $6 \mathrm{~d}, \mathrm{e}$ ), therefore indicative of diet regimes more prone to browsing on the leaves and bark of shrubs and trees. Although all of these variations and changes in morphotype composition are relative, it is clear that the phytolith records from dung pellets from free-ranging grazers, represented by sheep in the current study, could be potentially used as seasonality indicators.

Of particular note is the identification of diagnostic spheroid echinate phytoliths produced by the leaves of palms (Arecaceae) among the pig dung samples from both indoor and outdoor penning areas in Es Capell de Ferro (Figure 6f). During all the sampling seasons, we observed how adult pigs pluck and chew the leaves of three palms (Phoenix canariensis) naturally growing on the stabling floor, indicating the ingestion of the palm phytoliths through the mouth with their saliva (Figure 2g,h). According to our informants, the reason for chewing the leaves of palms remains unknown. Although pigs eat caloriedense foods their ability to extract energy from cellulose digestion is less efficient than in ruminant guts, oil-rich fibrous palm residues are reported as energy source in pig feeding fattening diets [59-61]. This particular case illustrates the non-deliberate inclusion within dung of other ingested plant microfossil remains rather than fodder. 

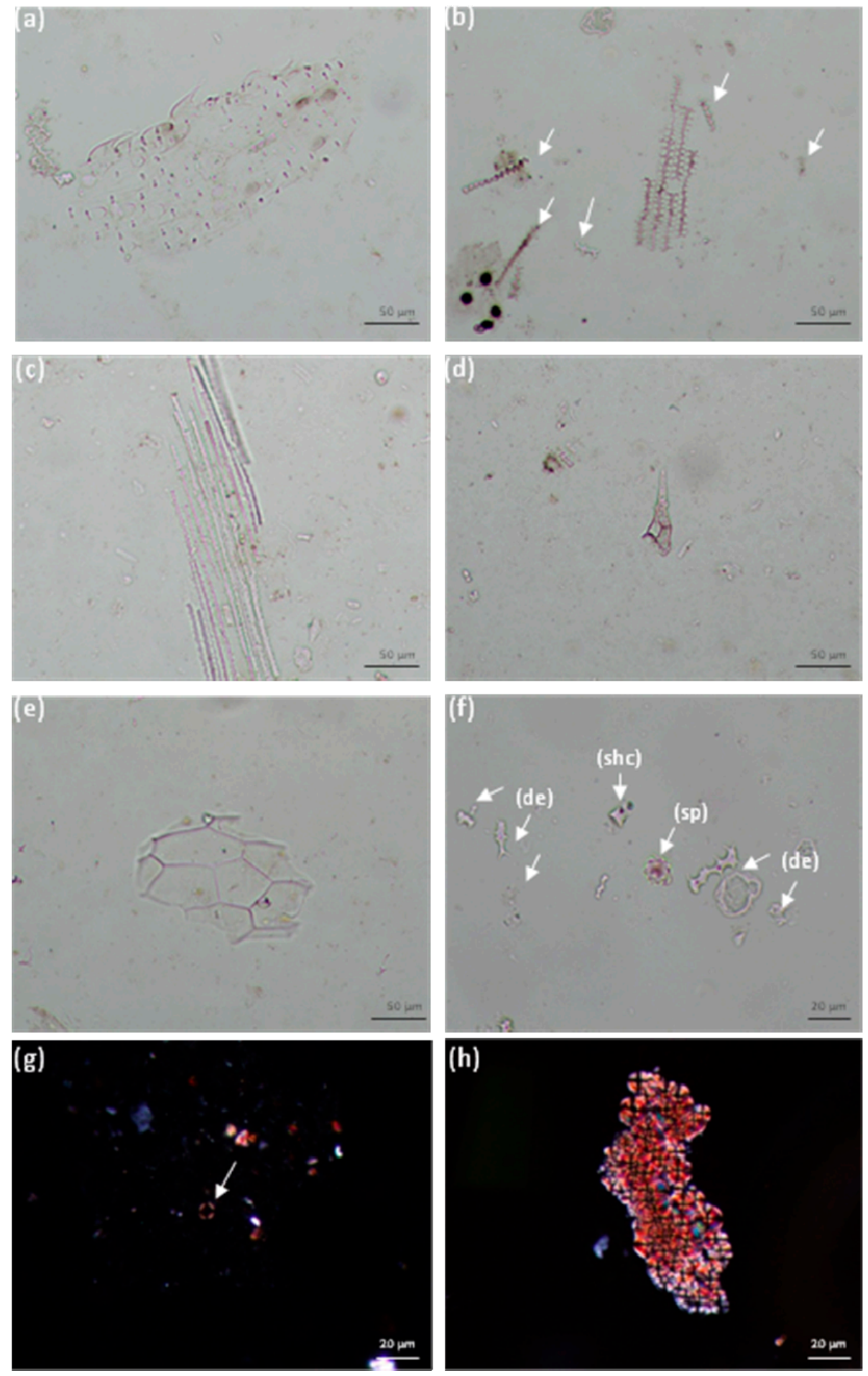

Figure 6. Photomicrographs of phytoliths and dung spherulites identified in the samples $(200 \times$ or $400 \times$ ). (a) multicelled (articulated) elongate psilate (smooth) phytoliths with short cell rondels and epidermal appendage acute bulbosus (trichomes) from the leaves of Pooideae grasses, sheep dung, sample 7-AN-S; (b) multicellular (articulated) dendritics with papillate, along with disarticulated dendritics (arrows) from grass inflorescences, pig dung, sample 18-CF-S; (c) multicellular (articulated) dendritics, cow dung, sample 6-AN-S; (d) epidermal appendage hair from dicotyledonous leaves, sheep dung, sample 29-TD-F; (e) epidermal appendage hair base from dicotyledonous leaves, cow dung, sample 6-AN-S; (f) spheroid echinate phytolith (sp) along with fragmented dendritics (de) and a short cell (shc), pig dung, sample 22-CF-S; (g) darkened dung spherulite at XPL, cow dung, sample 56-AN-J; (h) cluster of dung spherulites at XPL (none darkened), sheep dung, sample 29-TD-F. 
Overall, the morphological results indicated that most of the phytoliths derived from monocotyledonous plants and particularly grasses (around $90 \%$ of all the counted morphotypes, Table 4). The only exceptions were the sheep dung samples collected in winter from both farms, Algenderet Nou and Talatí de Dalt (samples coded as AN-F and TD$\mathrm{F}, \mathrm{ca} .85 \%$ ). This difference may be due again to the dietary regime of these flocks of herds, which graze in semi-freedom without any supplementary fodder. Interestingly, the same sheep dung samples have delivered the lowest ratios in terms of inflorescences/leaves and stems of grasses (Table 4). In contrast, animals with a diet based on cereal grains and flour from their own farms yielded the largest concentrations of phytoliths from the floral parts of cereal crops, barley in the case of pigs from Algenderet Nou (AN samples, ratios between 7.6-8.7) as well as from Es Capell de Ferro (CF samples, 6.2-6.6, Table 4 and Figure 7). Therefore, these markers characterized by relatively high proportions of diagnostic phytoliths from the floral parts of cereals within dung can be used as indicators of livestock supplementary fodder such as cereal grains and flours. An additional potential indicator for the use of crop flours as fodder would also be the index of multicellular or anatomically connected phytoliths, which is associated with the state of preservation produced by the mechanical degradation of multicelled morphologies during the grain cleaning and the grinding processes, as demonstrated through experimentally produced records on barley processing from Algenderet Nou [47], as previously argued. In summary, the modern dung reference standards obtained in the current study demonstrate that particularly the ratios of phytoliths produced by the inflorescences vs the leaves and stems of grasses, as well as ratios of individual (single-celled) vs anatomically connected (multicellular) phytoliths may serve as indicators of human manipulation in the feeding of livestock animals.

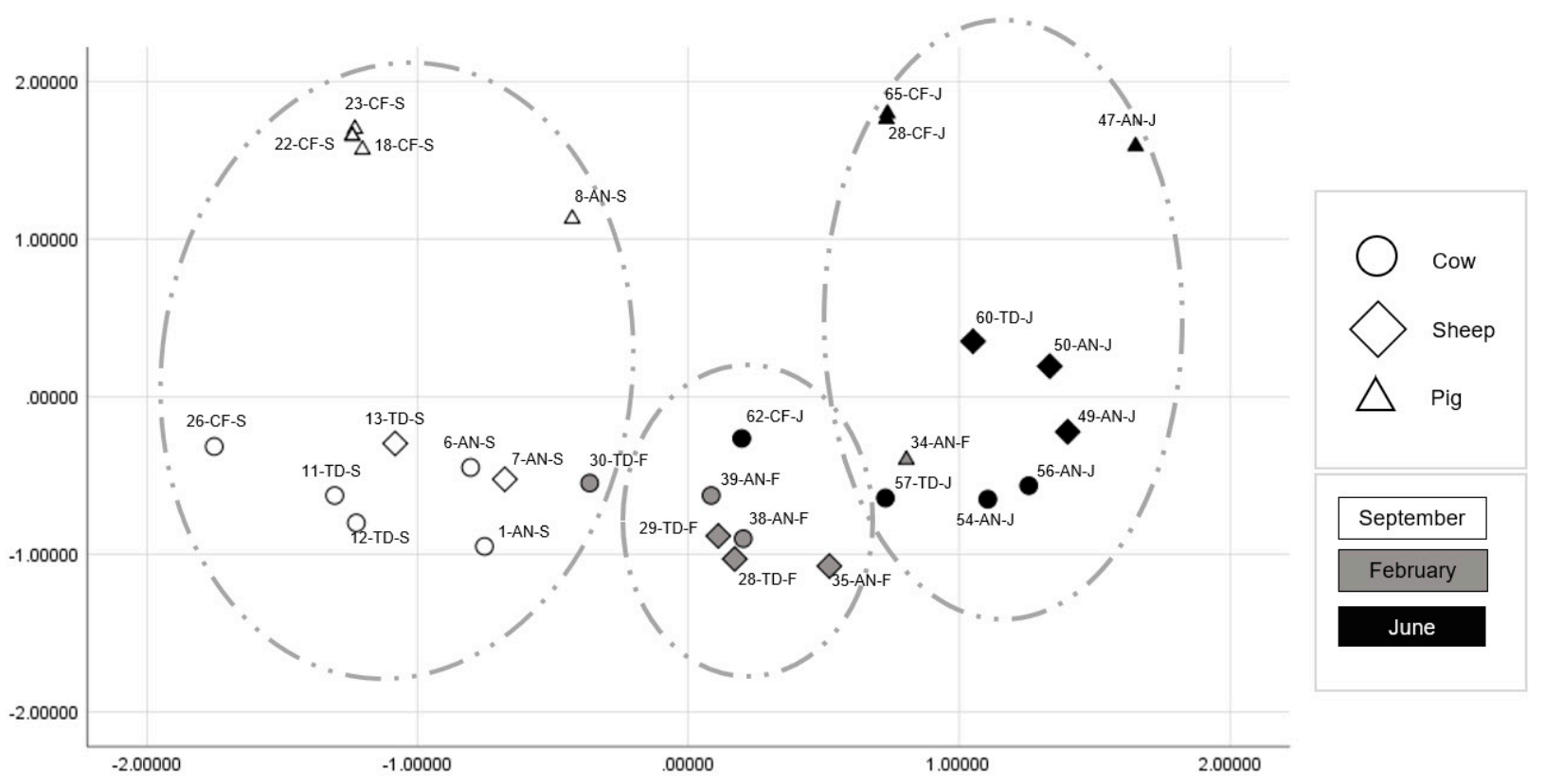

Figure 7. Principal component analysis (PCA) of grass inflorescences to leaves/stems ratios obtained from dung samples in relation to animal producers (cow, sheep, pig), farm (AN: Algendaret Nou, TD: Talatí de Dalt, CF: Es Capell de Ferro), and month (S: September, F: February, J: June,). Note that most of the samples tend to cluster according to animal producers, seasonality, and farm, particularly pigs (represented by triangles) with a diet based either on cereal grains or flour composed of large concentrations of grass inflorescences, and sheep grazers (in diamonds) with no supplementary fodder.

\subsection{Dung Spherulite Composition, Taphonomy and Seasonality}

Similarly to the phytolith quantitative analyses, the estimated dung spherulite numbers in Table 5 is based on abundances per weight of ashed dung material. The average percentages of total numbers of these calcitic microfossils were recorded for darkened or 
altered spherulites produced by ashing following the classification standards by Canti and Nicosia [24]. In those calcitic microremains the darkening spread across almost the whole spherulite and covers half or more of the overall diameter with a small clear fringe at its perimeter (Figure 6g). Darkened spherulites have been reported archaeologically in penning burnt spaces within caves and rock-shelters as well as in built environments as the result of the burning of dung including fuel remains $[3,58,62-66]$. The spherulite darkening has also been experimentally produced under increased heating laboratory-controlled combustions, occurring within a range between $500-700{ }^{\circ} \mathrm{C}$, with a maximum production at $650{ }^{\circ} \mathrm{C}$ under reducing conditions [24,25]. In the current study these are the result of the sample extraction whereby the organic matter is removed by ashing in the muffle furnace, as a common extraction procedure for phytolith and other calcitic microfossil integrated studies from modern dung and plant materials (at temperatures from $500-550{ }^{\circ} \mathrm{C}$ for $4 \mathrm{~h}$ ) e.g., $[9-11,25-27,29,67]$.

Table 5. Main quantitative calcitic spherulite results obtained from modern dung samples with indication of animal producer and known age (based on data from informants). Provenance (farm): AN: Algendaret Nou; TD: Talatí de Dalt; CF: Es Capell de Ferro. Month: S: September 2018; F: February 2019; J: June 2019.

\begin{tabular}{|c|c|c|c|c|}
\hline Sample n. & Location-Month & $\begin{array}{c}\text { Spherulites } 1 \text { g of Ashed } \\
\text { Material (Million) }\end{array}$ & Darkened Spherulites (\%) & Description \\
\hline 1 & AN-S & 0 & 0 & Cow (15 days) \\
\hline 6 & AN-S & 21 & 0 & Cow \\
\hline 7 & AN-S & 13.5 & 0.4 & Sheep \\
\hline 8 & AN-S & 0.3 & 0.4 & Pig \\
\hline 11 & TD-S & 4.8 & 0 & Cow \\
\hline 12 & TD-S & 4.7 & 0 & Cow (1 month) \\
\hline 13 & TD-S & 5.6 & 1.3 & Sheep \\
\hline 18 & CF-S & 0 & 0 & Pig \\
\hline 22 & CF-S & 0 & 0 & Pig \\
\hline 23 & CF-S & 0 & 0 & Pig (15 days) \\
\hline 26 & CF-S & 0 & 0 & Cow \\
\hline 28 & TD-F & 0.8 & 0 & Sheep (1 month) \\
\hline 29 & TD-F & 5.7 & 0.8 & Sheep \\
\hline 30 & TD-F & 4.5 & 0 & Cow \\
\hline 34 & AN-F & 0.6 & 0 & Pig \\
\hline 35 & AN-F & 10.9 & 0 & Sheep \\
\hline 38 & AN-F & 0.5 & 0.4 & Cow (3-4 months) \\
\hline 39 & AN-F & 7.3 & 0 & Cow \\
\hline 47 & AN-J & 0 & 0 & Pig \\
\hline 49 & AN-J & 9.1 & 0 & Sheep \\
\hline 50 & AN-J & 0.04 & 0 & Sheep (1 month) \\
\hline 54 & AN-J & 0.08 & 0 & Cow (1 month) \\
\hline 56 & AN-J & 5 & 0 & Cow \\
\hline 57 & TD-J & 8.7 & 0 & Cow \\
\hline 60 & TD-J & 19.2 & 0 & Sheep \\
\hline 62 & CF-J & 5.2 & 0.4 & Cow \\
\hline 65 & CF-J & 0 & 0 & Pig (2-3 months) \\
\hline 66 & CF-J & 0 & 0 & Pig \\
\hline
\end{tabular}

These calcitic microfossils were recorded isolated individually or in clusters of dung spherulites (Figure $6 \mathrm{~h}$ ). As expected, significant differences were noted in the current modern dung assemblages in calcitic spherulite distributions depending on the species of animal producers as well as their age e.g., [4]. Dung spherulite concentrations range between 0.04 and 21 million per $1 \mathrm{~g}$ of ashed dung, with the exceptions of all the pig dung samples, as well as the young two week old cow from Algenderet Nou (sample 1-AN-S) and an adult cow from Es Capell de Ferro (26-CF-S) where these calcitic microfossils were absent (Table 5). The heavy rain reported in the study area a few days before the sampling (end of September 2018) may explain the absence of dung spherulites in the sample from 
a non-fresh dried pellet by an adult cow found in the pasture grounds (Figure 2f), as these calcitic microremains are known to dissolve in acidic environments even in neutral $\mathrm{pH}$ conditions, including by rain water $[1,3,4]$. Of particular note are the comparatively relatively lower spherulite abundances recorded in dung fresh pellets from young animals around one month old (up to $0.8 \mathrm{~m}$ per $1 \mathrm{~g}$ spherulites/g of ashed dung), with the only exception of one of the adult cow remains from Talatí de Dalt (sample 12-TD-S, $4.7 \mathrm{~m}$ per 1 $\mathrm{g}$ spherulites/g of ashed dung). In general, these microscopic remains were noted in good state of preservation, and only five of the samples displayed morphologies altered by effects of controlled combustion in the laboratory in relatively low proportions (between $0.4-1.3 \%$ of the total counted spherulites, Table 5). Interestingly, there are no significant differences in relative distributions across different periods of the year either (Figure 8), although more detailed research is needed in order to assess possible seasonal changes or variations based on age/sex aspects on dung spherulite production and composition. Issues on spherulite production by ruminants in particular may therefore need to focus on grazers with any supplementary fodder that may interfere with the ingested material linked to spherulite formation in herd guts such as sheep and goat, as spherulite preservation may relate in part to the organic composition and porosity of the dung pellets, and cattle dung may be more fibrous and porous than ovicaprine pellets $[68,69]$. In addition, laboratory extraction ashing procedures must be taken in account, as the gaseous exchange inside the furnace oven in the case of oxidative heating with unpredictable burning conditions points to spherulite decrease and complete loss in burning experimental studies conducted on both cattle and ovicaprine pellets [24,25]. Modern dung reference standards will be expanded further to assess the variability in microfossil signatures as a result of exposure to fire under open-air conditions in experimental situations.

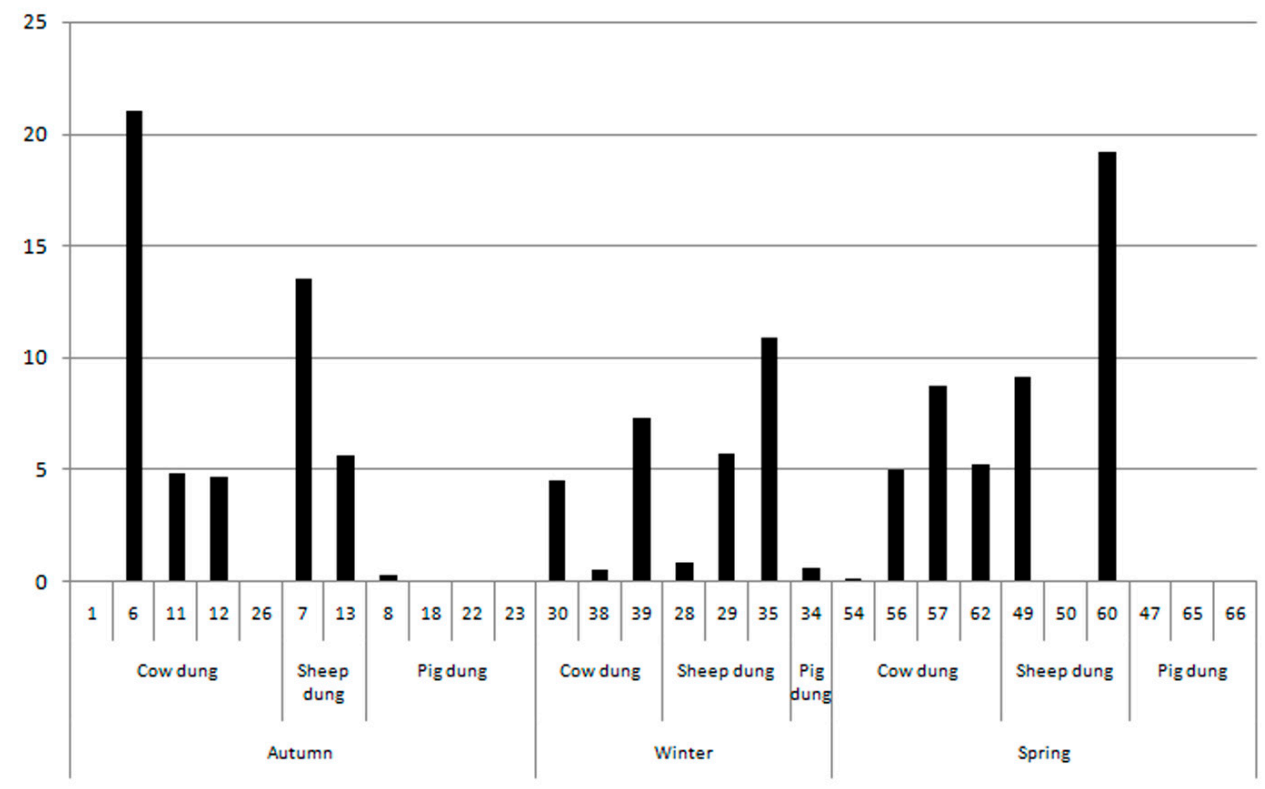

Figure 8. Plot showing average concentrations of dung spherulites obtained from dung samples.

\section{Conclusions}

This study contributes to our understanding of critical questions concerning dung origin, composition, taphonomy, and seasonality focusing on key parameters such as animal ecology, species and age, livestock management, grazing and foddering regimes and dietary habits, which have important implications for the identification and interpretation of plant and faecal microfossil archaeological records especially in agricultural and agropastoral archaeological contexts.

The phytolith records from the dung standards from ruminants and suids from the study area point towards clear changes in morphotype composition, but particularly 
regarding variations in the ratios of phytoliths produced by the inflorescences vs the leaves and stems of grasses, as well as on the ratios of individual (single-celled) vs anatomically connected (multicellular) phytoliths as potential markers of seasonality as well as foddering activity and human manipulation in livestock feed. Other factors affecting the composition of the phytolith records therefore may not be directly linked to foddering regimes, such as the inclusion of ingested plant remains from the leaves of palms chewed by pigs, illustrated in the current study.

In contrast, changes and variations on calcitic dung spherulite production and composition are not seen in relation to the type of feeding or on the seasonality. In fact, their production depends not only on the type of animal, with ruminants as the main producers, but also on its age, as pointed out in previous studies, although the available records regarding digestibility patterns according to age and sex patterns is still limited, to better establish possible differences between ruminants and suids for example. Further work is currently being carried out to assess aspects of digestibility and preservation of these and other remains excreted with dung (e.g., pollen grains, non-pollen palynomorphs-NPPs), as well as under increased heating (burning) open-air experimental situations.

Therefore, the modern dung reference datasets and the patterns reported in this study can be applied to compare and contrast microfossil dung assemblages from archaeological records, including the Balearic Islands and other inland contexts across the Mediterranean.

Author Contributions: Conceptualization, M.P. and K.D.; Methodology, M.P., K.D., M.A., D.R., Y.L. and A.F.; Software, M.P. and K.D.; Validation, M.P. and K.D.; Formal analysis, M.P. and K.D.; Investigation, M.P., K.D., M.A., D.R., Y.L. and A.F.; Resources, M.P., K.D., M.A., D.R. and A.F.; Data curation, M.P. and K.D.; Writing-original draft preparation, M.P. and K.D.; Writing-review and editing, M.P., K.D., M.A., D.R., Y.L. and A.F.; Visualization, M.P., K.D. and A.F.; Supervision, M.P.; Project administration, M.P.; Funding acquisition, M.P., Y.L., M.A. and D.R. All authors have read and agreed to the published version of the manuscript.

Funding: This research was funded by the Consell Insular de Menorca and the European Union's Horizon 2020 research and innovation program under the Marie Sklodowska-Curie MICROARCHEODUNG project, grant agreement No H2020-MSCA-IF-2015-702529. The funders had no role in the design of the study; in the collection, analyses, or interpretation of data; in the writing of the manuscript, or in the decision to publish the results.

Institutional Review Board Statement: The study was conducted according to the guidelines of the Declaration of Helsinki, and approved by the University of Reading Research Ethics Committee for the research with humans and domestic animals; the University of Reading Data Protection Officer confirmed that this research does not involve the collection/nor processing of personal sensitive data as defined under the UK Data Protection Act 1998 and Directive 95/46/EC of the European Parliament and of the Council of 24 October 1995.

Informed Consent Statement: Informed consent was obtained from all subjects involved in the study.

Data Availability Statement: Details on all data supporting the reported results can be found in Tables 1-5 and Figures 1-8, this original manuscript.

Acknowledgments: This study was made possible by support from the Consell Insular de Menorca and the Museu de Menorca. M.P. was a Marie Sklodowska-Curie at the University of Reading. The MICROARCHEODUNG project has received funding from the European Union's Horizon 2020 research and innovation programme under the grant agreement No H2020-MSCA-IF-2015-702529. K.D.'s research was supported by an AHRC South West and Wales Doctoral Training Partnership PhD studentship and placement at the University of Reading. She was a visiting research fellow at the Laboratory of Archaeobotany, Department of Prehistory, Autonomous University of Barcelona supervised by M.P. We are very grateful to Raquel Piqué and Karen Hardy (Department of Prehistory), as well as to Joan Manuel Soriano (Department of Geography) for access and further support at the laboratories of the Autonomous University of Barcelona. Special thanks are due to the families of Algendaret Nou, Talatí de Dalt and Es Capell de Ferro that welcomed us into their farms and homes and provided access to the samples and key information for this research.

Conflicts of Interest: The authors declare no conflict of interest. 


\section{References}

1. Shahack-Gross, R. Herbivorous livestock dung: Formation, taphonomy, methods for identification, and archaeological significance. J. Archaeol. Sci. 2011, 38, 205-218. [CrossRef]

2. Spengler, R.N. Dung burning in the archaeobotanical record of West Asia: Where are we now? Veg. Hist. Archaeobot. 2019, 28, 215-227. [CrossRef]

3. Brochier, J.E.; Villa, P.; Giacomarra, M.; Tagliacozzo, A. Shepherds and sediments: Geo-ethnoarchaeology of pastoral sites. J. Anthropol. Archaeol. 1992, 11, 47-102. [CrossRef]

4. Canti, M.G. The Production and Preservation of Faecal Spherulites: Animals, Environment and Taphonomy. J. Archaeol. Sci. 1999, 26, 251-258. [CrossRef]

5. Shahack-Gross, R.; Marshall, F.; Weiner, S. Geo-Ethnoarchaeology of Pastoral Sites: The Identification of Livestock Enclosures in Abandoned Maasai Settlements. J. Archaeol. Sci. 2003, 30, 439-459. [CrossRef]

6. Shahack-Gross, R.; Marshall, F.; Ryan, K.; Weiner, S. Reconstruction of spatial organization in abandoned Maasai settlements: Implications for site structure in the Pastoral Neolithic of East Africa. J. Archaeol. Sci. 2004, 31, 1395-1411. [CrossRef]

7. Macphail, R.I.; Cruise, G.M.; Allen, M.J.; Linderholm, J.; Reynolds, P. Archaeological soil and pollen analysis of experimental floor deposits; with special reference to Butser Ancient Farm, Hampshire, UK. J. Archaeol. Sci. 2004, 31, 175-191. [CrossRef]

8. Milek, K.B. Floor formation processes and the interpretation of site activity areas: An ethnoarchaeological study of turf buildings at Thverá, northeast Iceland. J. Anthropol. Archaeol. 2012, 31, 119-137. [CrossRef]

9. Portillo, M.; Valenzuela, S.; Albert, R.M. Domestic patterns in the Numidian site of Althiburos (northern Tunisia): The results from a combined study of animal bones, dung and plant remains. Quat. Int. 2012, 275, 84-96. [CrossRef]

10. Portillo, M.; Kadowaki, S.; Nishiaki, Y.; Albert, R.M. Early Neolithic household behavior at Tell Seker al-Aheimar (Upper Khabur, Syria): A comparison to ethnoarchaeological study of phytoliths and dung spherulites. J. Archaeol. Sci. 2014, 42, 107-118. [CrossRef]

11. Elliott, S.; Aziz, K.R.; Bendrey, R.; Whitlam, J.; Evans, J. Preliminary ethnoarchaeological research on modern animal husbandry in Bestansur, Iraqi Kurdistan: Integrating animal, plant and environmental data. Environ. Archaeol. 2015, 20, 283-303. [CrossRef]

12. Égüez, N.; Zerboni, A.; Biagetti, S. Microstratigraphic analysis on a modern central Saharan pastoral campsite. Ovicaprine pellets and stabling floors as ethnographic and archaeological referential data. Quat. Int. 2018, 483, 180-193. [CrossRef]

13. Wilding, L.P.; Drees, L.R. Biogenic opal in Ohio soils. Soil Sci. Soc. Am. J. 1972, 36, 383-385. [CrossRef]

14. Bartoli, F.; Wilding, L.P. Dissolution of biogenic opal as a function of its physical and chemical-properties. Soil Sci. Soc. Am. Proc. 1980, 44, 873-878. [CrossRef]

15. Piperno, D.R. Phytolith Analysis: An Archaeological and Geological Perspective; Academic Press: San Diego, CA, USA, 1988.

16. Piperno, D.R. Phytoliths: A Comprehensive Guide for Archaeologists and Paleoecologists; AltaMira Press: Lanham, MD, USA, 2006; ISBN 0759103844.

17. Albert, R.M.; Weiner, S. Study of phytoliths in prehistoric ash layers using a quantitative approach. In Phytoliths, Applications in Earth Sciences and Human History; Meunier, J.D., Colin, F., Eds.; A.A. Balkema Publishers: Lisse, The Nerherlands, 2001; pp. 251-266. ISBN 9789058093455.

18. Cabanes, D.; Weiner, S.; Shahack-Gross, R. Stability of phytoliths in the archaeological record: A dissolution study of modern and fossil phytoliths. J. Archaeol. Sci. 2011, 38, 2480-2490. [CrossRef]

19. Cabanes, D.; Shahack-Gross, R. Understanding Fossil Phytolith Preservation: The Role of Partial Dissolution in Paleoecology and Archaeology. PLoS ONE 2015, 10, e0125532. [CrossRef] [PubMed]

20. Wu, Y.; Yang, Y.; Wang, H.; Wang, C. The effects of chemical composition and distribution on the preservation of phytolith morphology. Appl. Phys. A 2014, 114, 503-507. [CrossRef]

21. Hodson, M.J. Phytoliths in Archaeology: Chemical Aspects. In Encyclopedia of Global Archaeology; Smith, C., Ed.; Springer International Publishing AG: Berlin, Germany, 2018.

22. Canti, M.G. The Micromorphological Identification of Faecal Spherulites from Archaeological and Modern Materials. J. Archaeol. Sci. 1998, 25, 435-444. [CrossRef]

23. Coil, J.; Alejandra Korstanje, M.; Archer, S.; Hastorf, C.A. Laboratory goals and considerations for multiple microfossil extraction in archaeology. J. Archaeol. Sci. 2003, 30, 991-1008. [CrossRef]

24. Canti, M.G.; Nicosia, C. Formation, morphology and interpretation of darkened faecal spherulites. J. Archaeol. Sci. 2018, 89, 32-45. [CrossRef]

25. Portillo, M.; Dudgeon, K.; Allistone, G.; Raeuf Aziz, K.; Matthews, W. The Taphonomy of Plant and Livestock Dung Microfossils: An Ethnoarchaeological and Experimental Approach. Environ. Archaeol. 2021, 26, 439-454. [CrossRef]

26. Tsartsidou, G.; Lev-Yadun, S.; Efstratiou, N.; Weiner, S. Ethnoarchaeological study of phytolith assemblages from an agro-pastoral village in Northern Greece (Sarakini): Development and application of a Phytolith Difference Index. J. Archaeol. Sci. 2008, 35, 600-613. [CrossRef]

27. Portillo, M.; Belarte, M.C.; Ramon, J.; Kallala, N.; Sanmartí, J.; Albert, R.M. An ethnoarchaeological study of livestock dung fuels from cooking installations in northern Tunisia. Quat. Int. 2017, 431, 131-144. [CrossRef]

28. Vergès, J.M.; Burguet-Coca, A.; Allué, E.; Expósito, I.; Guardiola, M.; Martín, P.; Morales, J.I.; Burjachs, F.; Cabanes, D.; Carrancho, Á.; et al. The Mas del Pepet experimental programme for the study of prehistoric livestock practices: Preliminary data from dung burning. Quat. Int. 2016, 414, 304-315. [CrossRef] 
29. Portillo, M.; Matthews, W. Investigating use of space and human-animal interactions in agricultural built environments: The geo-ethnoarchaeology of livestock dung. In Proceedings of the 11th International Congress on the Archaeology of the Ancient Near East, Munich, Germany, 3-7 April 2018; Otto, A., Herles, M., Kaniuth, K., Eds.; Harrassowitz Verlag: Wiesbaden, Germany, 2020; pp. 497-508.

30. Ramis, D. Estudio Faunístico de las Fases Iniciales de la Prehistoria de Mallorca. Ph.D. Thesis, Universidad Nacional de Educación a Distancia, Madrid, Spain, 2006.

31. Ramis, D. Early island exploitations: Productive and subsistence strategies on the prehistoric Balearic Islands. In The Cambridge Prehistory of the Bronze and Iron Age Mediterranean; Knapp, A.B., van Dommelen, P.A.R., Eds.; Cambridge University Press: New York, NY, USA, 2015; pp. 40-56.

32. Ramis, D. Evidències de contactes exteriors al món talaiòtic a partir de l'estudi del registre faunístic. In Menorca entre Fenicis $i$ Púnics; Prados, F., Jiménez, H., Martínez, J.J., Eds.; Centro de Estudios del Próximo Oriente y Antigüedad Tardía, Universidad de Murcia: Murcia, Spain, 2017; pp. 201-217.

33. Ramis, D. Animal Exploitation in the Early Prehistory of the Balearic Islands. J. Isl. Coast. Archaeol. 2018, 13, 265-278. [CrossRef]

34. Hernández-Gasch, J.; Ramis, D.; Rosselló, J.A. Economia, societat i canvi cultural a les Gimnèsies. La interpretació de les dades bioarqueològiques a les Illes Balears en el primer mil·lenni ane. In Economia Agropecuària i Canvi Social a Partir de les Restes Bioarqueologiques. El Primer mil-Lenni a C a la Mediterrània Occidental, Proceedings of the V Reunió Internacional d'Arqueologia de Calafell, Calafell, Spain, 16-18 April 2009; Valenzuela-Lamas, S., Padrós, N., Belarte, M.C., Sanmartí, J., Eds.; ArqueoMediterrània 12/2011; Universitat de Barcelona: Barcelona, Spain, 2011; pp. 123-138.

35. Anglada Fontestad, M.; Ferrer Rotger, A.; Plantalamor Massanet, L.; Ramis Bernad, D.; Van Strydonck, M. La sucesión de ocupaciones entre el Calcolítico y la Edad Media en el yacimiento de Cornia Nou (Menorca, Islas Baleares). The succession of occupations between the Chalcolithic and Middle Ages in the site of Cornia Nou (Minorca, Balearic Islands). Espac. Tiempo Forma. Ser. I Prehist. Arqueol. 2013, 6, 267. [CrossRef]

36. Portillo, M.; Llergo, Y.; Ferrer, A.; Anglada, M.; Plantalamor, L.; Albert, R.M. Actividades domésticas y molienda en el asentamiento talayótico de Cornia Nou (Menorca, Islas Baleares): Resultados del estudio de microfósiles vegetales. Rev. d'Arqueologia de Ponent 2014, 24, 311-321.

37. Pérez-Juez, A. Excavaciones en la Casa 2 del yacimiento de Torre d'en Galmés, Alaior: Propuestas para el hábitat talayótico. In L'arqueologia a Menorca, Proceedings of the III Jornades d'Arqueologia de les Illes Balears, Mahon, Spain, 3-4 October 2008; Gual Cerdó, J., Ed.; Consell Insular de Menorca: Mahon, Spain, 2011; pp. 119-130.

38. Pérez-Juez, A.; Goldberg, P.; Cabanes, D. Estudio interdisciplinar del hábitat post-talayótico: Bioarqueología, geoarqueología y registro arqueológico parala revisión metodológica de la arqueología en Menorca. In Economia Agropecuària $i$ Canvi Social a Partir de les Restes Bioarqueologiques. El Primer mil.Lenni aC a la Mediterrània Occidental, Proceedings of the V Reunió Internacional d'Arqueologia de Calafell, Calafell, Spain, 16-18 April 2009; Valenzuela-Lamas, S., Padrós, N., Belarte, M.C., Sanmartí, J., Eds.; ArqueoMediterrània 12/2011; Universitat de Barcelona: Barcelona, Spain, 2011; pp. 139-149.

39. Jansà, A. El clima del Migjorn. In Història Natural del Migjorn de Menorca. El Medi Físic i L'Influx Humà; Fornós, J.J., Obrador, A., Rosselló, V.M., Eds.; Societat d'Història Natural de les Balears: Palma, Spain, 2004; pp. 39-52.

40. Gornés, J.S.; Gual, J.M.; López, A.; De Nicolás, J.; Roca, A. L'assentament humà, des de la prehistòria fins al baix imperi. In Història Natural del Migjorn de Menorca. El Medi Físic i L'Influx Humà; Fornós, J.J., Obrador, A., Rosselló, V.M., Eds.; Societat d'Història Natural de les Balears: Palma, Spain, 2004; pp. 327-350.

41. Bolòs, O. La Vegetació de les Illes Balears: Comunitats de Plantes; Institut d'Estudis Catalans: Barcelona, Spain, 1996.

42. Tous de Sousa, C.; Roca Torrent, A.; Victory Pons, R.; Tripogney, N.; Massebeuf, M. Guia de Bones Pràctiques Energètiques en Explotacions de Vaca de Llet; Documenta Universitaria: Girona, Spain, 2016.

43. Ballester, P. Estudis d'Antropologia de Menorca; Institut Menorquí d'Estudis: Mahon, Spain, 1986.

44. Camps, A.; Elorduy, J. El Camp de Menorca. Patrimoni Etnologic Constrü̈t; Consell Insular de Menorca, Ajuntament de Ciutadella, "Sa Nostra" Caixa de Balears: Mahon, Spain, 1996.

45. Camps, A. L'elaboració tradicional del formatge i els seus derivats a Menorca. In Monografies Etnologiques del Museu Municipal de Ciutadella; Institut Menorquí d'Estudis: Ajuntament de Ciutadella, Spain, 1997; Volume 3, ISBN 84-86752-60-4.

46. Sintes, A. Trulls i Tafones. La Producció d'oli a Menorca; S'Auba Edicions Llevant S.C.: Sant Lluís, Spain, 2013.

47. Portillo, M.; Llergo, Y.; Ferrer, A.; Albert, R.M. Tracing microfossil residues of cereal processing in the archaeobotanical record: An experimental approach. Veg. Hist. Archaeobot. 2017, 26, 59-74. [CrossRef]

48. Katz, O.; Cabanes, D.; Weiner, S.; Maeir, A.M.; Boaretto, E.; Shahack-Gross, R. Rapid phytolith extraction for analysis of phytolith concentrations and assemblages during an excavation: An application at Tell es-Safi/Gath, Israel. J. Archaeol. Sci. 2010, 37, 1557-1563. [CrossRef]

49. Tsartsidou, G.; Lev-Yadun, S.; Albert, R.-M.; Miller-Rosen, A.; Efstratiou, N.; Weiner, S. The phytolith archaeological record: Strengths and weaknesses evaluated based on a quantitative modern reference collection from Greece. J. Archaeol. Sci. 2007, 34, 1262-1275. [CrossRef]

50. Albert, R.M.; Shahack-Gross, R.; Cabanes, D.; Gilboa, A.; Lev-Yadun, S.; Portillo, M.; Sharon, I.; Boaretto, E.; Weiner, S. Phytolithrich layers from the Late Bronze and Iron Ages at Tel Dor (Israel): Mode of formation and archaeological significance. J. Archaeol. Sci. 2008, 35, 57-75. [CrossRef] 
51. Albert, R.M.; Ruíz, J.A.; Sans, A. PhytCore ODB: A new tool to improve efficiency in the management and exchange of information on phytoliths. J. Archaeol. Sci. 2016, 68, 98-105. [CrossRef]

52. Twiss, P.C.; Suess, E.; Smith, R.M. Morphological Classification of Grass Phytoliths. Soil Sci. Soc. Am. Proc. 1969, 33, 109-115. [CrossRef]

53. Brown, D.A. Prospects and limits of a phytolith key for grasses in the central United States. J. Archaeol. Sci. 1984, 11, 345-368. [CrossRef]

54. Rosen, A.M. Preliminary Identification of Silica Skeletons from Near Eastern Archaeological Sites: An Anatomical Approach. In Phytolith Systematics; Springer: Boston, MA, USA, 1992; pp. 129-147.

55. Twiss, P.C. Predicted World Distribution of C3 and C4 Grass Phytoliths. In Phytolith Systematics; Springer: Boston, MA, USA, 1992; pp. 113-128.

56. Mulholland, S.C.; Rapp, G. A Morphological Classification of Grass Silica-Bodies. In Phytolith Systematics; Springer: Boston, MA, USA, 1992; pp. 65-89.

57. Neumann, K.; Strömberg, C.; Ball, T.; Albert, R.M.; Vrydaghs, L.; Cummings, L.S. International Code for Phytolith Nomenclature (ICPN) 2.0 International Committee for Phytolith Taxonomy. Supplementary Information: Glossary of Descriptive Terms. Ann. Bot. 2019, 124, 189-199.

58. Portillo, M.; García-Suárez, A.; Matthews, W. Livestock faecal indicators for animal management, penning, foddering and dung use in early agricultural built environments in the Konya Plain, Central Anatolia. Archaeol. Anthropol. Sci. 2020, 12, 1-15. [CrossRef] [PubMed]

59. Ong, H.K. The use of palm oil sludge solids in pig feeding. In Proceedings of the 1st Asian-Australasian Animal Science Congress, Serdang, Malaysia, 2-5 September 1980; UPM Press: Serdang, Malaysia, 1982; pp. 307-311.

60. Ocampo, A. Oil-rich Fibrous Residue from African Oil Palm as Basal Diet of Pigs; Effects of Supplementation with Methionine. Livest. Res. Rural Dev. 1992, 4, 55-59.

61. Ocampo, A. Raw palm oil as the energy source in pig fattening diets and Azolla filiculoides as a substitute for soya bean meal. Livest. Res. Rural Dev. 1994, 6, 8-17.

62. Brochier, J.-E. Cayönü Tepesi. Domestication, rythmes et environnement au PPNB. Paléorient 1993, 19, 39-49. [CrossRef]

63. Castel, C.; Archambault, D.; Martin, L.; Quenet, P.; Sanz, S.; Vila, E.; Awad, N.; Barge, O.; Boudier, T.; Brochier, J.; et al. Rapport préliminaire sur les activités de la mission archéologique franco-syrienne dans la micro-région d'Al-Rawda (Shamiyeh): Quatrième et cinquième campagnes (2005 et 2006). Akkadica 2008, 129, 5-54.

64. Polo Díaz, A.; Martínez-Moreno, J.; Benito-Calvo, A.; Mora, R. Prehistoric herding facilities: Site formation processes and archaeological dynamics in Cova Gran de Santa Linya (Southeastern Prepyrenees, Iberia). J. Archaeol. Sci. 2014, 41, 784-800. [CrossRef]

65. Polo-Díaz, A.; Alonso Eguíluz, M.; Ruiz, M.; Pérez, S.; Mújika, J.; Albert, R.M.; Fernández Eraso, J. Management of residues and natural resources at San Cristóbal rock-shelter: Contribution to the characterisation of chalcolithic agropastoral groups in the Iberian Peninsula. Quat. Int. 2016, 414, 202-225. [CrossRef]

66. Portillo, M.; García-Suárez, A.; Klimowicz, A.; Barański, M.Z.; Matthews, W. Animal penning and open area activity at Neolithic Çatalhöyük, Turkey. J. Anthropol. Archaeol. 2019, 56, 101106. [CrossRef]

67. Gur-Arieh, S.; Mintz, E.; Boaretto, E.; Shahack-Gross, R. An ethnoarchaeological study of cooking installations in rural Uzbekistan: Development of a new method for identification of fuel sources. J. Archaeol. Sci. 2013, 40, 4331-4347. [CrossRef]

68. Brönnimann, D.; Ismail-Meyer, K.; Rentzel, P.; Pümpin, C.; Lisá, L. Excrements of herbivores. In Archaeological Soil and Sediment Micromorphology; Nicosia, C., Stoops, G., Eds.; John Wiley and Sons Ltd.: Oxford, UK, 2017; pp. 55-65.

69. Dalton, M.; Ryan, P. Variable Ovicaprid Diet and Faecal Spherulite Production at Amara West, Sudan. Environ. Archaeol. 2020, 25, 178-197. [CrossRef] 